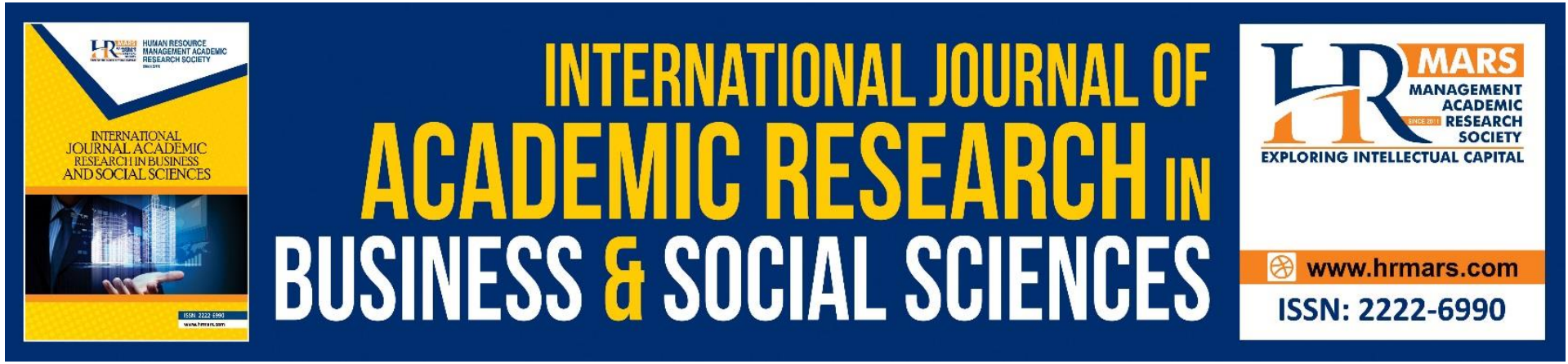

\title{
Language Learning Strategies (LLS) used by the Form Four Male Secondary School Students in Speaking Skill
}

Vilogini Chandra Segaran, Shamini Sanmugam, Mohammad Izuan Ismail, Nur Amalina Jaafar Siddek, Siti Sarah Musthaffa Kamal, Harwati Hashim

To Link this Article: http://dx.doi.org/10.6007/IJARBSS/v11-i7/10253 DOI:10.6007/IJARBSS/v11-i7/10253

Received: 06 May 2021, Revised: 10 June 2021, Accepted: 05 July 2021

Published Online: 28 July 2021

In-Text Citation: (Segaran et al., 2021)

To Cite this Article: Segaran, V. C., Sanmugam, S., Ismail, M. I., Siddek, N. A. J., Kamal, S. S. M., \& Hashim, H. (2021). Language Learning Strategies (LLS) used by the Form Four Male Secondary School Students in Speaking Skill. International Journal of Academic Research in Business and Social Sciences, 11(7), 13821394.

Copyright: (c) 2021 The Author(s)

Published by Human Resource Management Academic Research Society (www.hrmars.com)

This article is published under the Creative Commons Attribution (CC BY 4.0) license. Anyone may reproduce, distribute, translate and create derivative works of this article (for both commercial and non-commercial purposes), subject to full attribution to the original publication and authors. The full terms of this license may be seen at: http://creativecommons.org/licences/by/4.0/legalcode

Vol. 11, No. 7, 2021, Pg. 1383 - 1394

http://hrmars.com/index.php/pages/detail/IJARBSS

JOURNAL HOMEPAGE

Full Terms \& Conditions of access and use can be found at http://hrmars.com/index.php/pages/detail/publication-ethics 


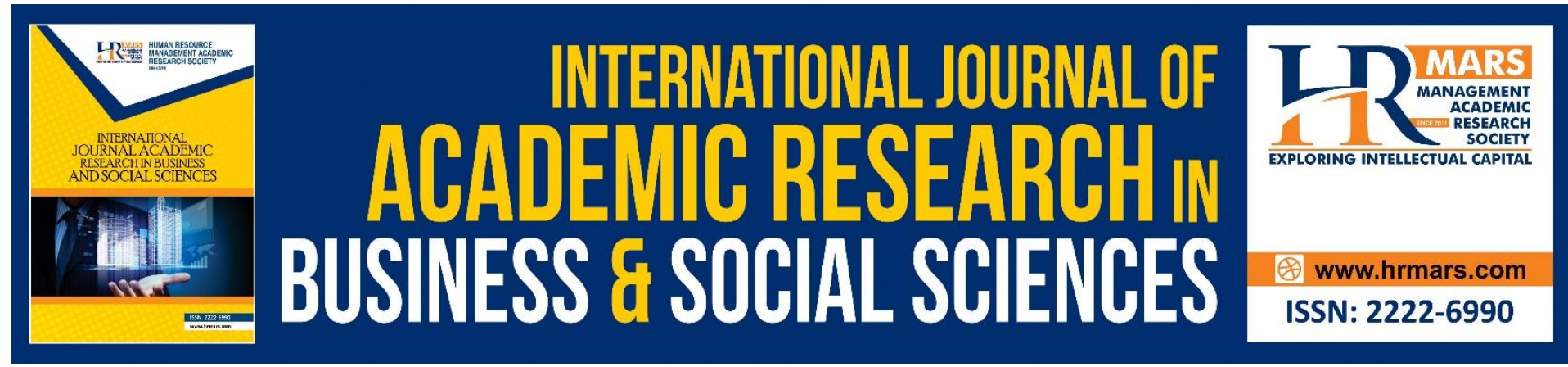

\title{
Language Learning Strategies (LLS) used by the Form Four Male Secondary School Students in Speaking Skill
}

\author{
Vilogini Chandra Segaran ${ }^{1,6}$, Shamini Sanmugam ${ }^{2,6}$, \\ Mohammad Izuan Ismail| ${ }^{3,6}$, Nur Amalina Jaafar Siddek ${ }^{4,6}$, Siti \\ Sarah Musthaffa Kamal' ${ }^{5,6}$, Harwati Hashim ${ }^{6}$ \\ ${ }^{1}$ SK Ulu Semenyih, Selangor, ${ }^{2}$ SMK St Paul, Seremban, ${ }^{3}$ SK Sungai Pusu, Kuala Lumpur, ${ }^{4}$ SK \\ Taman Melawati, Kuala Lumpur, ${ }^{5}$ SRAI Salak Tinggi, Selangor, ${ }^{6}$ Faculty of Education, \\ University Kebangsaan Malaysia, Bangi, Malaysia
}

\begin{abstract}
English as an international language serves its importance in many fields such as finance, medicine, technology and education. The four main skills in the acquisition of English are speaking, listening, reading and writing. In order to converse well in this global world, speaking skill is the most important for communication. Language learners deploy many strategies such as cognitive, metacognitive, compensation affective, social and memory strategies to enhance the speaking skills. Therefore, this study is aimed to investigate the language learning strategies employed by Form Four male students. A mixed method design was employed with semi structured interviews and questionnaires as the instruments for data collection. In this intervention, 40 Form 4 students from a secondary school in Negeri Sembilan were selected as the participants. The findings of this paper showed that the most frequent language learning strategies implemented were social, affective and memory strategies in the acquisition of speaking skill. Based on this finding, more studies are expected to be conducted to identify the application of other skills to help the students strive in learning English.
\end{abstract}

keywords: Language Learning Strategy, Speaking Skill, Form 4, Secondary School

\section{Introduction}

Language is the most important tool used for communication purposes across the world. Any language is important in order for the people to survive in their lives. There are four main skills to be mastered in English Language, which are reading, writing, listening and speaking. Among these skills, priority is devoted to speaking because spoken language emphasizes the primacy compared to written language (Torky, 2006). Therefore, mastering speaking skill, is vital as successful language learners are measured via their ability to converse in English accurately and fluently.

Occasionally, most learners face difficulties in speaking English. Students often feel afraid to express themselves in a foreign language (Hashemi, 2011). They often feel anxious, 
shy and worried about making mistakes. In accordance with that, effective learning strategies can help an individual to master a language at ease. Thus, Language Learning Strategies (LLS) is one of the aspects which influence the acquisition of the English language among learners.

Learning strategies are methods, techniques and approaches used by the learners to aid language learning (Oxford \& Crookall, 1989). It facilitates the learners to acquire a language at ease. Cognitive, metacognitive, compensation, affective, social, and memory strategies are among the language learning strategies that can be used by learners to acquire a language successfully. The success in language learning is strongly bound to one's language learning techniques. It has been discovered that language learning techniques are linked to proficiency and success.

Many past studies focused on the relationship between gender and language learning strategy used in learning English as a general and very limited study on male learners' language learning strategy for speaking skills. A few studies showed that in comparison to males, females were better at using language learning strategies (Ping and Lee, 2016). Other studies revealed that in terms of achievement tests, females outperform males by a wide margin, and they used more language learning strategies, suggesting that those language learning strategies are positively useful in learning English successfully (Aslan, 2009; HongNam \& Leavell, 2006).

Despite the fact that there have been several studies on gender roles and language learning strategies, there appears to be a lack of study on ESL male learners' speaking strategies. In accordance with this, this study aims to study the language learning strategy used by the Form Four Male Secondary School Students in Speaking Skill. This study was structured based upon the following research objectives:

1) To identify the language learning strategies used by the form four male students in speaking skill.

2) To identify the frequent language learning strategies used to increase fluency and accuracy in speaking skill.

\section{Literature Review \\ Speaking Skill}

Within these four language skills, speaking is considered to be the most vital that needs to be learnt and mastered in learning a new language. According to Nunan (1991) to achieve success in speaking skills the most vital aspect of learning foreign language and the result will be assessed in terms of capability to bring in the conversation in that language. Meanwhile, speaking in a second language is not difficult to master. A beginner considers speaking as the most strenuous skill as it needs a lot of courage and strength as well as preparation to attempt to speak well in the new language. Brown (2004) applauds speaking has five aspects which are consist of grammar, vocabulary, comprehension, fluency and pronunciation. Prior to further, the speakers must know what need and want to say, hence speakers need to generate the ideas in order to spill out what they will want to say about. Furthermore, to be able to speak eloquently, the learners must have ample and adequate lexicons and must be able to systematize the sentences as the listeners will easily understand. Thereupon, the learners will be qualified to speak successfully and the listeners will wellconversed the message easily. Regarding this, Richard (2008), people who are speaking are prone to getting something done, exploring ideas, working out some aspects of the world and simply being together. 


\section{Language Learning Strategy}

Language learning is divided into two main categories which are direct and indirect strategies (Oxford, 1991). Presently, the direct strategies he came up with Oxford and Crookall (1989), has remarked out that this strategy encompassed memory strategies, cognitive strategies and compensation strategies.

\begin{tabular}{|c|c|}
\hline \multicolumn{2}{|l|}{ Direct strategies: } \\
\hline \multirow[t]{4}{*}{ 1. Memory strategies } & -Creating mental linkages \\
\hline & -Applying images and sounds \\
\hline & -Reviewing well \\
\hline & -Employing action \\
\hline \multirow[t]{4}{*}{ 2. Cognitive strategies } & -Practising \\
\hline & -Receiving and sending messages \\
\hline & -Analysing and reasoning \\
\hline & - Creating structure for input and output \\
\hline \multirow[t]{2}{*}{ 3. Compensation strategies } & - Guessing intelligently \\
\hline & $\begin{array}{l}\text { - Overcoming limitations in speaking and } \\
\text { writing }\end{array}$ \\
\hline \multicolumn{2}{|l|}{ Indirect strategies: } \\
\hline \multirow[t]{3}{*}{ 1. Metacognitive strategies } & - Centring your learning \\
\hline & -Arranging and planning your learning \\
\hline & -Evaluating your learning \\
\hline \multirow[t]{3}{*}{ 2. Affective strategies s } & - Lowering your anxiety \\
\hline & - Encouraging yourself \\
\hline & - Taking your emotional temperature \\
\hline \multirow[t]{3}{*}{ 3. Social strategies } & -Asking questions \\
\hline & -Cooperating with others \\
\hline & -Empathising with others \\
\hline
\end{tabular}

Memory strategies are techniques to help learners to reserve new information in memory and recover it later. Furthermore, cognitive strategies entail manipulation or transformation of the language in some direct ways such as jot down and note taking. Hence, compensation strategies are behaviours used to compensate for missing knowledge. Apart from that, according to Oxford and Crookall (1989) consist of metacognitive, affective and social strategies. Hence, metacognitive or the other name frequently called beyond the cognitive strategies are used to provide control over the learning process.

Besides that, affective strategies are techniques to gain better control over a learner's emotion and finally the social strategies are actions involving other people in the language learning process. According to O"Malley and Chamot (1990, p. 1) t "learning strategies are special thoughts or behaviors that individuals use to help them comprehend, learn, or retain new information". Notably, learning strategies are specific actions taken by learners to help their own learning, to make the learning easier, faster, more enjoyable, more self-directed, more effective and more transferable (Oxford, 1990). Regarding this statement, by encompassing the precise and exact techniques and strategies, the progression of learnedness of the language will be refined significantly.

\section{Classification of Language Learning Strategy}

Learning strategies refers to the correlation or the mediating mechanism that exists between learner factors and learner outcomes. 
Therefore, EFL teachers' competency has been categorized clearly and specifically by the three theories of Mulhauser (1958); Richards (1998); Cross (2003). These three theories indicated constant domains of what an EFL teacher should know and be able to do (Soepriyatna, 2012).

Oxford (1990, p. 14-16) has been categorized clearly and specifically language learning strategies into six groups: (1) memory strategies which are the strategies that assist learners supply and recover new information, (2) cognitive strategies which are strategies that allow learners to comprehend and create new language by dissimilar meaning vocabulary, (3) compensation strategies which are strategies that support learners to solve knowledge gaps and sustained liaise genuinely (4) affective strategies which are referring to the strategies that able to build up self-confidence, (5) metacognitive strategies which are strategies that assist learners to synchronize their own cognitive potential and to focus, plan, and evaluate their progress as they move toward contextual capacity, and (6) social strategies pointed out strategies that put up increased communication and more assertive interpretation. All appropriate language learning strategies may able prone to the aim of goal of becoming interactively competency.

\section{Past Studies on Language Learning Strategy in Speaking Skill}

Yasmin, Nazima, and Ezzati (2018) did a research on Secondary School Students' Language Learning Strategies for Improving Speaking Skills and the results revealed that two most commonly employed strategies by students in speaking skills are compensatory and practising strategies. Based on the responses from the interview, students agreed that practising strategies were the most productive strategies which contribute to the improvement of their speaking abilities. Many students felt that speaking abilities are linked to output production. Thus, they stated that production of their output (through speaking) becomes better and smoother when they use the language consistently in their daily conversation. Aside from that, the researchers noticed that throughout their conversations, female students employed more language learning strategies than male students.

Mistar and Umamah (2014) did another study on the Language Learning Strategies used by Indonesian English Learners for Speaking Skills and Their Contribution to the Speaking Proficiency. It revealed that there were six types of speaking skill strategies employed by the learners in their speaking skill and among these six strategies, four main strategies which contribute to the speaking proficiency among learners were the interactional-maintenance, self-improvement, compensation, and memory strategies. Based on the data analysis, female learners reported higher intensity use of these strategies compared to male learners. The finding implied that these four main strategies need to be incorporated specifically in the classroom to enhance speaking skill proficiency among learners, especially male learners.

Gani, Fajrina, and Hanifa (2015) revealed in their study on Students' Learning Strategies for Developing Speaking Ability that compensation and social strategies were the two main strategies utilised by learners with poor speaking ability. Students with better speaking proficiency, on the other hand, had a better balance in using these language learning strategies to enhance their speaking ability. In order to improve their speaking abilities, these students used all six strategies at the same frequency-compensation, social, affective, memory, cognitive and metacognitive strategies.

Although many studies have been undertaken on language learning strategies and gender roles, there appears to be a lack of study on ESL male learners' speaking skill strategies. 


\section{Methodology \\ Research Design}

A mixed-methods research design was used in this study. Instruments used to collect data are semi-structured interviews and a survey questionnaire adapted from Oxford (1990).

\section{Research Participants}

The research was conducted at a national secondary school in Seremban, Negeri Sembilan. The participants of this study were 40 students from the Upper Secondary Level. They were Form Four (4) students. The students were basically from the third class out of seven classes where the school practices the streaming system in order to group students according to their ability in the learning process. The students are average users of English based on their examination performance. Upper-level students were chosen by the researchers because they had been learning English for several years in the school.

\section{Research Instruments}

This study used questionnaires adapted from Oxford (1990) and semi-structured interviews as the research instrument to collect the data needed for this research. 30 items out of 50 items from "The Strategy Inventory for Language Learning" (SILL) were chosen as the instruments for evaluating participants' language learning strategies.

In the questionnaire used with the participants, Part A was on memory strategies, Part $B$ was on cognitive strategies, Part $C$ was on compensation strategies, Part $D$ was on organising and evaluating learning, Part $\mathrm{E}$ was on managing emotions, and Part $\mathrm{F}$ was on learning together with others. The SILL's five-point scale went from "never or almost never" to "always or almost always." to help students better understand the statement. The overall average score indicated how often the learner applied learning strategies in general, while the average score for each strategy group indicated which strategies the participants used most frequently.

Semi-structured interview questions were formulated based on past research by (Gani et al., 2015). There were 17 interview questions asked by the researchers to 6 out of 40 participants in this research. This was performed to verify the participants' learning strategies. The responses were transcribed to be analyzed by the researchers to find out the language strategies frequently used by the participants.

\section{Data Collection Procedure}

The data were collected to investigate what are the language learning strategies used and the most frequent language learning strategies used by the male students in their speaking skills. Distribution of questionnaires for quantitative data was carried out according to the researcher's planned schedule in giving the questionnaire and participants' comfort time. Completed questionnaires were then returned to the researchers on the same day. In addition, semi-structured interview sessions were conducted individually to six students who have volunteered themselves sincerely to be interviewed by the researchers. Consent forms were enclosed together with the questionnaires distributed in advance. Data from the questionnaire were gathered and quantified. The data were further coded to classify the participants' language learning strategies frequently used. Semi-structured interviews with six participants lasted for more than 2 hours. Verbatim transcription was employed to the data obtained. Analysis of data was carried out and organized to answer the research questions: 1) what are the language learning strategies used in speaking skills by the form 
four students and 2) which strategies are frequently used by the form four students in improving fluency and accuracy in speaking skills. Students' responses were recorded and presented in a categorical manner. Some measures were taken into consideration by the researchers including validation of questions for semi-structured interviews beforehand with a certified language expert.

Table 1: SILL Worksheet Version 7.0

\begin{tabular}{|c|c|c|}
\hline PART & STRATEGY & CLASSIFICATION \\
\hline A & MEMORY & \multirow{2}{*}{ DIRECT STRATEGIES } \\
\hline B & COGNITIVE & \\
\hline C & COMPENSATION & \multirow{2}{*}{ INDIRECT STRATEGIES } \\
\hline D & METACOGNITIVE & \\
\hline E & AFFECTIVE & \\
\hline F & SOCIAL &
\end{tabular}

Table 2: Oxford's (1990) Conversion on Frequency of the Use of Strategy and Mean Score

\begin{tabular}{|c|c|c|}
\hline \multicolumn{2}{|c|}{ SCALE } \\
\hline \multirow{2}{*}{ High } & $\begin{array}{c}\text { Always / Almost always true } \\
\text { of me }\end{array}$ & 4.5 to 5.0 \\
\cline { 2 - 3 } & Generally it's me & 3.5 to 4.4 \\
\hline Medium & Partly it's me & 2.5 to 3.4 \\
\hline \multirow{2}{*}{ Low } & Generally not me & 1.5 to 2.4 \\
\cline { 2 - 3 } & $\begin{array}{c}\text { Never / Almost never true of } \\
\text { me }\end{array}$ & 1.0 to 1.4 \\
\hline
\end{tabular}

\section{Findings and Discussion}

The findings show that the form four students use all learning strategies for their speaking performances. However, the form four students frequently used Social Strategies in their speaking performance. This was identified through the questionnaire and interview process.

\section{Data from Questionnaire}

All 40 participants of the form four students completed the questionnaire without leaving any unattempted statement. Results on the questionnaire are illustrated in the table below. 
Table 3: SILL Results for the Form Four Students

\begin{tabular}{|c|c|c|}
\hline Parts of Learning Strategies & Average & Interpretation \\
\hline Part A: Memory Strategy & 4.6 & High \\
\hline Part B: Cognitive Strategy & 3.8 & High \\
\hline Part C: Compensation Strategy & 4.6 & High \\
\hline Part D: Metacognitive Strategy & 3.1 & Medium \\
\hline Part E: Affective Strategy & 4.5 & High \\
\hline Part F: Social Strategy & 4.4 & High \\
\hline
\end{tabular}

The results obtained from the form four students showed an average of 4.6 for Memory Strategy, an average of 3.8 for Cognitive Strategy, an average of 4.6 for Compensation Strategy, an average of 3.1 for Metacognitive Strategy, an average of 4.5 for Affective Strategy and an average of 4.4 for Social Strategy. The numbers showed that all participants have utilised all the SILL learning strategies. The participants showed a very high level of using Memory Strategy, Cognitive Strategy, Compensation Strategy, Affective Strategy and Social Strategy compared to Metacognitive Strategy which the participants partly agreed that it is used in their English speaking skills.

These findings indicate that the form four students know of their strategies for language learning, and that they utilise various strategies, such as remembering, using mental processes, compensating for knowledge gaps, coping with emotions, and learning with others.

\section{Data from Interview}

The number of students' language learning strategies gained categorized further as follows from the interview session: 
INTERNATIONAL JOURNAL OF ACADEMIC RESEARCH IN BUSINESS AND SOCIAL SCIENCES

Vol. 11, No. 7, 2021, E-ISSN: 2222-6990 @ 2021 HRMARS

Table 4: List of Students' Language Learning Strategies Used

\begin{tabular}{|c|c|c|c|c|c|c|c|}
\hline \multicolumn{8}{|c|}{ Language Learning Strategies Used } \\
\hline & \multicolumn{3}{|c|}{ Direct Strategies } & \multicolumn{3}{|c|}{ Indirect Strategies } & \multirow[b]{2}{*}{ Total } \\
\hline $\begin{array}{c}\text { Student } \\
\text { s }\end{array}$ & $\begin{array}{l}\text { Memory } \\
\text { Strategies }\end{array}$ & $\begin{array}{l}\text { Cognitive } \\
\text { Strategies }\end{array}$ & $\begin{array}{l}\text { Compensation } \\
\text { Strategies }\end{array}$ & $\begin{array}{c}\text { Metacognitive } \\
\text { Strategies }\end{array}$ & $\begin{array}{c}\text { Affective } \\
\text { Strategie } \\
\text { s }\end{array}$ & $\begin{array}{c}\text { Social } \\
\text { Strategies }\end{array}$ & \\
\hline I. & 4 & 1 & 2 & 1 & 5 & 4 & 17 \\
\hline II. & 2 & 1 & 4 & 1 & 4 & 5 & 17 \\
\hline III. & 3 & 3 & 2 & 1 & 4 & 4 & 17 \\
\hline IV. & 4 & 2 & 2 & 1 & 3 & 5 & 17 \\
\hline V. & 2 & 3 & 3 & 1 & 5 & 3 & 17 \\
\hline VI. & 3 & 1 & 3 & 2 & 3 & 4 & 17 \\
\hline Total & 18 & 11 & 16 & 7 & 24 & 25 & 102 \\
\hline
\end{tabular}

Based on the table above, there were six male students selected from different groups of proficiency who used different language learning strategies in speaking. The most frequent language learning strategies used were social strategies, affective strategies and then memory strategies. The other language learning strategies also used but less frequently; compensation strategies, cognitive strategies and metacognitive strategies.

Based on the findings above, each strategy used by the students would be discussed from the highest to the lowest frequency as follows:

\section{1) Social Strategies}

Most of the students were able to use social strategies extensively. The students applied this strategy when asking help from their peers, during small group discussions and working in pairs to produce good speech. They need help from their peers specially to check the pronunciation of unknown words. This is shown from the data collected as below:

"I also consult my friends and teachers when I am at school."

According to O'Malley \& Chamot (1990), social strategies involve oneself and others, for example, cooperating with peers and seeking clarification. Implementation of a small group discussion to assure the pronunciation also takes place regularly. Students also looked for their friends who are proficient to acquire fluent speech as seen below.

"My English was not that good when I was younger so I mingled with them and this has contributed to my current fluency in English". 


\section{2) Affective Strategies}

Students frequently employ the affective learning strategy. The affective strategy employed through lowering anxiety and encouraging oneself helps them be confident while delivering speech.

"Yes. I move my hands and walk when I share my opinion with someone if I'm interested in that matter".

The students were able to participate in the conversation when they were interested in the subject discussed. Moreover, the students' motivation to speak increases when they are confident with the language.

"I prefer to be explosive and expressive, with flamboyant hand gestures, and also meek and timid movements, all dependent on the context of the thing I am speaking about. The most important part is being confident, for me at least."

\section{3) Memory Strategies}

The students employed this strategy by writing new vocabulary in a book, reading the text and watching western movies. The memory strategy helps students to increase the fluency of speech by increasing the interaction with many resources.

"I particularly enjoy speaking in a British English Accent, and I pay attention to British movies and TV shows, and speak to British friends to pick up on the accent. Similarly for an American accent."

\section{4) Compensation Strategies}

The compensation strategy applies when students use gestures to support their speech. The students applied this strategy to strengthen the meaning of the words that they articulate.

"I move parts of my body to show the meaning of the word or sentence they don't understand. A simple example is I nod my head to represent "yes" and shake my head to represent "no".

\section{5) Cognitive Strategies}

The cognitive strategy used to manipulate the target language or to complete given tasks correctly. Most of the students employed cognitive strategies to drill and practice the language or to find meaning of unknown words and terms in online dictionaries and google translate.

"When I am doubtful of the pronunciation of some words, I enter the words into Google Translate or Google to listen to the pronunciation".

\section{6) Metacognitive strategies}

The students employ metacognitive strategies when they do self-preparation by monitoring their own speech and do evaluation to improve accuracy.

"I look at sample essays and analyse my mistakes and correct them. Therefore, improving my grammar".

Based on the discussion above, the language learning strategies applied by the students will be classified in table as follows:

Table 5 : The Classification of Students' Language Learning Strategies 


\begin{tabular}{|l|l|}
\hline \multicolumn{1}{|c|}{ Learning Strategies } & \multicolumn{1}{|c|}{ Components } \\
\hline \multirow{2}{*}{ Social Strategies } & 1. Asking a help \\
\cline { 2 - 2 } & 2. Working in pair \\
\cline { 2 - 2 } & 3. Participate in small discussion \\
\hline \multirow{2}{*}{ Affective Strategies } & 1. Motivation \\
\cline { 2 - 2 } & 2. Lowering anxiety \\
\cline { 2 - 2 } & 3. Encouraging oneself \\
\hline \multirow{2}{*}{ Memory Strategies } & 1. Read a text \\
\cline { 2 - 2 } & 2. Watch western movies \\
\hline \multirow{2}{*}{ Compensation strategies } & 1. Evaluation \\
\hline \multirow{2}{*}{ Metacognitive strategies } & 2. Find similar meaning \\
\cline { 2 - 2 } & \\
\hline
\end{tabular}

\section{Conclusion}

The study's findings revealed that learners used a variety of language learning strategies to improve their speaking ability. The participants showed a very high level of using compensation, cognitive, affective, memory and social strategies compared to metacognitive strategy which the participants partly agreed that it is used in their English-speaking skills based on the data of questionnaire however the data from the interview showed the most frequent language learning strategies used were social strategies, affective strategies and then memory strategies. The other language learning strategies also used but less frequently; compensation strategies, cognitive strategies and metacognitive strategies.

Furthermore, the association is considerable, implying that speaking learning strategies are likely to influence the students' speaking performance assessment score. Students who employ various speaking learning strategies to improve their speaking abilities are more likely to achieve good speaking scores. Effective language learners apply language learning strategies consciously, according to (Oxford, 1996; Wenden, 1990). It signifies that pupil who employed various speaking learning strategies were able to communicate effectively in the language. 


\section{References}

Aslan, O. (2009). The role of gender and language learning strategies in learning English (Master's thesis).

Gani, S. A., Fajrina, D., \& Hanifa, R. (2015). Students' learning strategies for developing speaking ability. Studies in English Language and Education, 2(1), 16-28.

Hashemi, M. (2011). Language stress and anxiety among the English language learners. Procedia Social and Behavioral Sciences, 30, 1811-1816.

Ho, A. P., \& Ng, L. L. (2016). Gender-based differences in language learning strategies among undergraduates in a Malaysian public university. Issues in Language Studies, 5(2).

Hong-Nam, K., \& Leavell, A. G. (2006). Language learning strategy use of ESL students in an intensive English learning context. System, 34(3), 399-415.

Mistar, J., and Umamah, A. (2014). Strategies of learning speaking skill by Indonesian learners of English and their contribution to speaking proficiency. Teflin Journal, 25(2), 203-216.

Zakarial, N. Y. K., Zakaria, S. N., Azmi, N. E. (2018). Language Learning Strategies Used by Secondary Schools Students in Enhancing Speaking Skills. Creative Education, 9(14), 2357-2366.

Oxford, R., \& Crookall, D. (1989). Research on language learning strategies: Methods, findings, and instructional issues. The modern language Journal, 73(4), 404-419.

Torky, S. A. E. (2006). The Effectiveness of a Task-Based Instruction Program in Developing the English Language Speaking Skills of Secondary Stage Students. Online Submission.

Sreena, S., \& Ilankumaran, M. (2018). Developmental Speaking as A Strategy to Enhance Communication Skills - A Cognitive Based Approach. International Journal of Engineering \& Technology 